Lorena Cebolla Sanahuja. Lecturer of Political Philosophy at the University of Trento. Her research interests rest mainly in the field of political philosophy, concretely in the history and contemporaneity of cosmopolitanism, global justice, the political philosophy of Immanuel Kant and poststructuralist perspectives in political philosophy. Among her latest publications: "Kant's Apple: The Moral Grounding of Right and the Interdependence of Ethics and Law", in Studia Kantiana, 16, pp. 65-90, 2014; "El concepto kantiano de propiedad", in Con-textos kantianos, 2, pp. 347-359, 2015; "The right of the subject to become a citizen of the world: Kant anti-colonial cosmopolitanism", in Cosmopolitanism: Between Ideals and Reality, pp. 59-82, L. Cebolla Sanahuja and F. Ghia (eds.), Cambridge Scholars, UK, 2015.

Contact: lorena.cebolla@unitn.it 


\title{
EUROPE COSMOPOLITICAL \\ OR POPULIST: JUSTICE AND \\ SOFT POWER IN PERSPECTIVE
}

\author{
Lorena Cebolla Sanahuja
}

Università degli Studi di Trento

DOI: 1017450/160206

Reception date $30^{\text {th }}$ June 2016; acceptance date $20^{\text {th }}$ July 2016. This article is the result of research activities held at the Dipartimento di Lettere e Filosofia, Università degli Studi di Trento.

\section{Abstract}

Today Europe faces a dilemma: to be cosmopolitical or not to be. The peril of disintegration of the European Union announced by the recent Brexit results and the rise of right-wing populism through Europe calls for an exercise in soft power by the European Union in matters regarding political negotiation and conflict mediation within its space. This capacity seems, however, to be missing. This paper defends that, in order to regain a consistent soft power, the European Union must devise a hegemonic strategy aimed at constructing a European liquid identity from a democratic subject position that might be defined as strongly cosmopolitan.

\section{Keywords}

Soft power, populisms, hegemony, cosmopolitanism, justice. 


\section{Resumen}

Europa afronta hoy un dilema: ser cosmopolita o dejar de serlo. El peligro de desintegración de la Unión Europea anunciado por los resultados del reciente brexit y por el auge de los populismos de derecha en toda Europa reclama un ejercicio de soft power por parte de la Unión Europea en materias relacionadas con la negociación y la resolución de conflictos en su espacio interno. Esta capacidad, sin embargo, parece estar ausente. Este artículo defiende que, para recuperar una capacidad consistente de soft power, la Unión Europea tiene que diseñar una estrategia hegemónica destinada a construir una identidad europea líquida, a partir de una posición de sujeto democrático que puede definirse como fuertemente cosmopolita.

\section{Palabras clave}

Soft power, populismos, hegemonía, cosmopolitismo, justicia. 


\section{Introduction}

The most pressing matters on political negotiation and mediation for the EU have become internal. The peril of the EU disintegration calls for an exercise in soft power, but the Grexit, the Brexit, and the right-wing populism in different European countries, such as France, Austria or the Netherlands, speak of a lack of strategy for political dialogue and mediation, as well as of a void concerning a European identity able to articulate the different positions at play in the European arena.

These days Europe faces a dilemma, to be cosmopolitical or not to be. This seemingly presumptuous choice between what seems to be a utopian notion and a dystopian future is in reality a choice between, on the one hand, a much needed construction of a new European identity and tradition, a change in economic and social policies within the European Union and a continuation in strengthening and enlarging the politics of human rights application and, on the other hand, a progressive, sad and painful erosion and disappearance of Europe as a political-economic and social entity.

The danger to Europe as a political reality and as a project has been focalized lately in the crescent rise of right-wing populisms across Europe. In fact, populism, or right wing populism to be exact, is correctly analyzed as a response to the Europeanization process that begins in the 80 's, together with the crisis and effects of neoliberal economy ${ }^{1}$. The Brexit results are the clearest effect of this populism that is not state-centered, but that constructs the idea of a people through its opposition to an international political body. In this sense, right populism has created "the people" through a re-creation of the anticolonial discourse, with Europe (its bureaucrats, the troika and/or simply Germany or France) as the oppressive colonial mother and its states as the exploited colonies. The $\mathrm{EU}$ is been thus used as the main negativity or opposite in order to create new identities, that, at least until this moment, does not seem to be able to consistently resist after a real break happens ${ }^{2}$.

1. See for example: M. Berezin, Illiberal Politics in Neoliberal Times, Cambridge University Press, Cambridge (UK), 2009 ; D. Albertazzi, D. Macdonell (eds.), Twenty-first Century Populism The Spectre of Western European Democracy, Palgrave Macmillan, Houndmills-Basingstoke-Hampshire, 2008; J. Rydgren (ed.), Movements of Exclusion: Radical Right-Wing Populism in the Western World, Nova Science Publishers, New York, 2005.

2. This seems at least to be the case in the UK after the success of the "leave" votes at Brexit. A dissolution of populism and a reenactment of the traditional political positions and the varied subjects they represent seem to have re-occupied the position of "the people" that the UKIP's discourse constructed. This is reflected in the general UK's atmosphere of astonishment regarding the Brexit result, as if "the people" confronting Europe had been the monster of a nightmare which effects have overcome the realm of the unconscious and appeared in the one of reality. 
The immigration problem has functioned in this scenario as a common denominator for the elaboration of a peoplehood constructed according to the logic of a hegemonic strategy: a unity arising above a manifold of positions that have in common a general dissatisfaction towards institutions because of their incapacity to respond to their claims, and that become one or united when a certain discourse or rhetoric articulates their demands and dissatisfactions upon a contingent commonality. The xenophobic or racist discourse that stays at the basis of many European populisms has evolved into a discourse for which "the immigration problem" represents the key to reunite all the social problematics that result from a neoliberal economy subjected to endemic crisis; a discourse that has its articulatory basis in the lost of state sovereignty that follows the Europeanization process and that perceives in the European Union a usurper of power and the main cause for the degradation of the welfare state. This discourse is, of course, not based on a void, but it follows a progressive impoverishment of the European middle-class and a perilous precarious situation of the lower clases since the 2008 crisis. This general degradation of the social conditions within the EU has shown a lack of mediation between the powerless and the powerful, one that is evident in the failure of the EU political parties to represent aggregated interests and to transform them into concrete politics aimed at lessening this gap ${ }^{3}$.

Brexit "leave" results are thus a direct consequence of this perception of the EU as a sovereign phantom that interferes in domestic issues robbing state governments of their capacity to attend to social problematics, instead aggravating them without offering a response to the social gap in the exchange. A situation that, as mentioned above, has found in the immigrant crisis the scapegoat to the general discomfort regarding the consequences neoliberal economy has for social security and stability.

This perception of "Europe bureaucrat" is accompanied by another one that sees in the European Union and in European citizenship a polity. This is mainly the understanding of Europe that young generations (generations $\mathrm{Y}$ and $\mathrm{Z}$ ) profess, since they are generations that grew and/or were born European and for whom Europe has a meaning that might compete with the one the nation-state has. A perception shared also by many of the older generations that contemplate Europe as the warrant and bastion of peace, democracy and justice. It is also an understanding projected outwards, a perception of Europe as a united "confederation-federation" of the states that form a unique polity. The internal perception is not without its problems, and has revealed itself in the 
popular backing of the Greek people in their demands of debt negotiation as well as (even though in a much more informal or opaque manner) in the recent petitions that have spread these days in social and other mass media of another referendum in Britain following the public regrets that some British have expressed regarding their votes for leaving the EU ${ }^{4}$. Merkel's declaration that Britain's EU exit did not need to be an accelerated process turned into a message of hope for young British, even though it rapidly changed into a menacing warning regarding the terms of the future UK-EU relations. The benevolent perception of the EU is thus double faced, regarding Europe as a polity of common identity as well as an object of critique regarding the effects of excessively stringent economic policies. It reflects, in this sense, a generalized lack of consistent soft power by the EU towards its own members.

\section{Soft power from within, hegemonic strategies}

The classical definition of soft power presents it as "the ability to get what you want

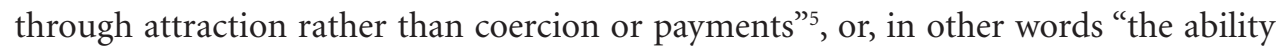
to make others want the same as you want, through attraction rather than coercion"6. Tools of soft power are thus culture, political values and norms, economic, social and legal policies that are considered to be praiseworthy because pursue desirable and legitimate ends, enshrined effectively, in the case of the EU, in texts such as the Charter of Fundamental Rights of the European Union.

The soft power that the EU has as a global actor based on these sources of influence has been extensively analyzed ${ }^{7}$. But what about the soft power that the EU has regarded its own members? EU power within the EU space is mainly a function of the different actors of which it is composed. The willingness that all the EU states manifest of being part of the EU, or the EU soft power regarding its own members can be explained

\footnotetext{
4. See as an example the following press releases the days following the Brexit results: http://www.bbc.com/news/uk-politics-eu-referendum-36629324.

http://www.telegraph.co.uk/news/2016/06/28/petition-for-second-eu-referendum-hits-4-million-as-hundreds-att/. http://qz.com/716947/four-ways-the-uk-can-reverse-brexit-if-it-really-really-wants-to/.

http://www.abc.net.au/news/2016-06-25/young-brits-declare-brexit-result-not-in-my-name/7543316.

5. J. S. Nye, Soft Power: The Means to Success in World Politics, Public Affairs, New York, 2004.

6. K. L. Nielsen, "EU Soft Power and the Capability -Expectations Gap", in Journal of Contemporary European Research, 9 , 5, 2013, pp. 723-39, p. 724.

7. See as example R. Ginsberg, "Conceptualizing the European Union as an International Actor: Narrowing the Theoretical Capability-Expectations Fap”, in Journal of Common Market Studies, 37, 3, pp. 429-54; J. McCormick, The European Superpower, Palgrave Macmillan, Houndmills-Basingstoke-Hampshire, 2006.
} 
exactly, or in the same terms, as that of its potential members. There seems to be no further articulation of European attractiveness beyond the elements that configure it as an external tool of international power. Instead, it seems that within its borders the EU functions more and more as a source of hard power, lately and mainly under the form of sanctions regarding economic breaches from EU directives. In other words, there is not an EU politics of hegemony or a hegemony force or power of the EU that can exercise a soft power able to articulate its different unities such as the one exercised by the right-wing populist movements. This is probably because the European Union is understood, within the European space, to be basically or essentially formed not as a subject or as an identity, but as a composite of autonomous subjects united mainly by economic interests. Paradoxically, this lack of any type of subject underlying a complexity of autonomous differences has been analyzed by the political philosophers of hegemony as the adequate point of departure from where to construct of a democratic hegemony in the contemporary reality of industrialized democracies ${ }^{8}$. But the opportunity to elaborate a hegemonic strategy from this starting point is being ignored or left to itself, risking this way a perception of the EU, as we said, not as a unit of articulation of differences that might be able to exercise a strong soft power towards itself, but as a mere bureaucratic economic-oriented entity that, without this hegemonic democratic strategy, faces the peril of becoming the perfect objective of populist politics and their hegemonic discursivity.

To create a new source of soft power, able to figure and function as a nodal point for conflict mediation towards the inside of the European Union through a hegemonic strategy that aims to explicitly construct a European $\operatorname{demos}^{9}$, might be the only solution to confront the right-wing populist discourses.

The hegemonic strategy consists mainly in a unifying discursive strategy that is able to articulate around a unit or subject a series of autonomous positions that present or represent their own independent demands or requests, within a field of antagonistic forces. In contemporary societies crisis are endemics, and the field of conflictuality is ever present. The understanding of the contemporary conflictuality has been clarified by Laclau and Mouffe, who explain it, as well as the emergence of new political subjects, as part of the democratic revolution, as a result of: "commodification and bureaucrati-

\footnotetext{
8. E. Laclau, Ch. Mouffe, Hegemony and Socialist Strategy: Towards a Radical Democratic Politics, Verso, London-New York, 2001(2nd ed.).

9. As opposed to a construction of the demos in a spontaneous manner resulting from the perception of a common identity through shared ends. This was the analysis of the European strategy by G. Ash, "Catching the Wrong Bus? Europe's Future and the Great Gamble of Monetary Union”, in Times Literary Supplement, 5 May 1995.
} 
zation of social relations on one hand, and the reformulation of the liberal-democratic ideology -resulting from the expansion of struggles for equality- on the other" ${ }^{10}$. This is why today the autonomous or independent demands present themselves as claims for equality, because contemporary democracies are defined in function of the redefinition of the liberal-democratic ideology, that displaced the struggle form liberty to the struggle from equality, from "equality of opportunities to equality of results, and from equality between individuals to equality between groups"11, and as thus, "liberty has become to mean the 'capacity' to make certain choices and to keep open a series of real alternatives. It is thus that poverty, lack of education, and great disparities in the conditions of life are today considered offences against liberty" ${ }^{12}$. Thus, it is clear that "capacitation" has become one of the key concerns of all contemporary hegemonic discourses. It is around this concept that hegemonic discourses arise, defining the individual and its potentialities through it, establishing a rhetoric that depending on the treatment of this matter becomes ultimately totalitarian or, as we will propose to the EU, radically democratic.

The difference between a hegemonic discourse and strategy for the EU such as the one we present here and the hegemonic discourse populisms exercise stays in the fact that the former should be defined from the starting point of a democratic subject position. That is, while populisms construct their hegemonic discourse through a division of the political in two, by the construction of "the people" through the identifying and opposition of "the oppressor" (the cast, class, élite, bureaucrats, etc.), a democratic hegemonic discursivity does not need of this division, but should insist in the new political configuration of our societies, and establish a hegemony that instead of creating two confronting subjects highlights the differences and autonomous positions defining the multitude of contemporary existing political spaces. An articulation of differences that does not pursue thus the creation of a fixed identity or a totalitarian subject (and so without the need to identify the negative element that determines such a positive identity), but that insists in the current democratic shaping of our societies, multiplying the political spaces, multiplying thus the spaces for identification, affiliation, discussion, requests...

If the aim of the hegemonic democratic strategy is the creation of such a "liquid identity", Europe, as the speaker of a discourse on legitimacy, has the vantage

10. E. Laclau, Ch. Mouffe, Hegemony and Socialist Strategy, p. 163.

11. Ibid., p. 166.

12. Ibid., p. 172. 
point that it can become a hegemonizing subject without becoming a fixed subject summarizing a closed totality. Given the multiplicity of identities and legacies due to its very structure, Europe does not need to construct its identity around the label "European citizenship", but can instead develop a discourse that includes more focal points than that of citizenship, such as economy, ecology, genre..., manages to create the equivalence necessary for a hegemonic position through the articulation of varied and continuously transforming positions that summarize the mobile positions of the individual, understood then not as a "determined individual" but as a "liquid individual"13. The EU seems to be working, however, in a direction that complements the neoconservative perspective that is proper of right-wing politics and populisms, that is, depoliticizing the fundamental decisions on economic and social policies through the removal of public decisions from political control and addressing them to the responsibility of experts.

The hegemonic strategy that follows a democratic subject positions has, in addition, the vantage that the contingency and variability that define it might result paradoxically stable when confronted with a populist hegemonization, that needs to reinforce their discourse and insist in the negative element that defines it continuously, since otherwise the different autonomies conforming the notion of people dissolve in their original antagonistic positions spontaneously ${ }^{14}$.

Accompanying the hegemonic discursivity that aims for the articulation of differences through the creation of a liquid or plastic European identity must exist as well a "set of proposals for the positive organization of the social"15. When a hegemonic discourse has no further objective than the creation of a negativity, that is, the obtaining and maintenance of power, then we are facing a kind of politics that is purely populist ${ }^{16}$. If, however, the hegemonic strategy aims to construct and reinforce the social and political space as democratic, then it needs to be accompanied by this kind of positive proposals that must count as additional sources of the existence of a soft power, and that have to be adequate for the democratic position it stems from.

\footnotetext{
13. We understood liquid individual as the adjective that corresponds to the individual in the liquid modernity coined by Zygmunt Bauman. In this case, the indeterminacy and insecurity attached to the subject's identity are rescued to give them a positive outcome as the result of a hegemonic democratic strategy whose aim is to multiply the political spaces where the individual discusses and confronts the chaos and insecurity that springs from its position in the globalized society. See. Z. Bauman, Liquid Modernity, Polity Press, Cambridge, 2000.

14. For this and further points on the character of populisms see the recent book of J. L. Villacañas, Populismo, La Huerta Grande, Madrid, 2015.

15. E. Laclau, Ch. Mouffe, Hegemony and Socialist Strategy, p. 189.

16. For a complete and complex analysis on populism see E. Laclau, On Populist Reason, Verso, London, 2005.
} 
To concretize the idea, the construction of the European identity, the creation of a subject of soft power toward its inside, might be constructed through a hegemonic strategy that presents the EU within Europe and for Europe as something more than a union of all its participants and of their respective democracies in a bureaucratic unit that works under the flag of the defense of human rights. The EU hegemonic strategy and its soft power should consist in becoming more than a democratic power, presenting itself as a cosmopolitan hegemonic power. And this because cosmopolitanism includes democracy as one of its components, while at the same time supersedes the latter with a series of premises and objectives that reflect more adequately the new contemporary configuration of social conflictuality.

\section{The cosmopolitan strategy}

Cosmopolitanism is a complex concept or notion in the sense that it reunites under a common heading a multiplicity of thoughts that regard the ethical, the moral, the political, the economic, the cultural, etc. At the basis of all these perspectives stays the centrality and desirability of the idea of a community of all humans that is viewed both as an interpretative concept as well as a desirable aim for our existing fragmented world. Cosmopolitanism in this multiple sense has, as has correctly noticed Georg Cavallar ${ }^{17}$, a dynamic nature, in the sense that it is a concept that has suffered along history an evolution, a widening in its content while as the same time considers its object, the community of all humans, as itself dynamic, that is, as an object to come, as a project instead of as something already given, conceived mainly as a contingent object, that is, of indefinite cause, form and content.

In what has already become the classical definition of cosmopolitanism by Thomas Pogge, we can summarize its essence as follows:

Three elements are shared by all cosmopolitan positions. First, individualism: the ultimate units of concern are human beings or persons rather than, say, family lines, tribes, ethnic, cultural, or religious communities, nations or states. The latter may be units of concern only indirectly, in virtue of their individual members or citizens. Second, universality: the status of ultimate concern attaches to every

17. G. Cavallar, "Dynamic Cosmopolitanism: A brief Sketch with a Special Emphasis on Kant”, in L. Cebolla, F. Ghia, (eds.), Cosmopolitanism: Between Ideals and Reality, Cambridge Scholars, Newcastle, 2015, pp. 35-58. 
living human being equally not merely to some sub-set, such as men, aristocrats, Aryans, whites, or Muslims. Third, generality: this special status has global force. Persons are ultimate units of concern for everyone-not only for their compatriots, fellow religionists, or such like ${ }^{18}$.

In recent years, the debate on cosmopolitanism in the political philosophical literature has taken mainly two approaches. One is related to the design of international institutions, and is well represented by the thought of David Held and Daniele Archibugi and their proposal of a cosmopolitan democracy. The other has to do with global justice, Charles Beitz and the diverse proposal for wealth redistribution at the global level by Thomas Pogge, Hillel Steiner and Paula Casal might be considered the most relevant references within this branch ${ }^{19}$. Held and Archibugi's design of a cosmopolitan democracy presents it like a form of a parliament or assembly of democracies, that, as the Kantian idea of a federation of republics, functions as a center of attraction for the other non-democratic countries that stand towards it in an ongoing relation of eventual membership based, precisely, on the traditional sources of soft power this nucleus of democratic states have. The other cosmopolitan trend is preoccupied with a mechanism of taxation to realize global justice.

At the basis of all these perspectives stays the idea of a global community of law, that is, of a community in which all the subjects have the same fundamental rights and duties, while at the same time enjoy different cultures and diverse configurations of the social and political spaces where duties and rights are reified. A community where national and regional borders do not signify limitations regarding the exercise of those rights and duties, but the porous limits cultural, political and social configurations, an idea of a community of communities, where the individual is not thought of as a pre-social entity but as deeply embedded in multiple groups and levels of allegiance.

18. T. Pogge, "Cosmopolitanism and Sovereignty", in Ethics, 103, 1992, pp. 48-75, pp. 48-49.

19. See as reference texts: Ch. Beitz, "Justice and International Relations", in Philosophy and Public Affairs, 4, 4, 1975, pp. 360-89; Ch. Beitz, “Cosmopolitan Ideals and National Sentiment”, in The Journal of Philosophy, 80, 10, pp. 591-600; D. Held, “Democracy: From City-States to a Cosmopolitan Order?", in Political Studies, 40, 1992, pp.10-139; D. Archibugi, The Global Commonwealth of Citizens. Toward Cosmopolitan Democracy, Princeton University Press, Princeton, 2008 ; Th. Pogge, World Poverty and Human Rights, Polity Press, Cambridge, UK, 2008 (2n ed.); H. Steiner, "Just Taxation and International Redistribution", in Nomos, 41, 1999, pp. 171-191; P. Casal, "Global Taxes on Natural Resources", in Journal of Moral Philosophy, 8, 2011, pp. 307-327; H. Steiner, “The Global Fund: A Reply to Casal”, in Journal of Moral Philosophy, 8, 2011, pp. 328-34; Th. Pogge, "Allowing the Poor to Share the Earth", in Journal of Moral Philosophy, 8, 2011, pp. 335-352. 
The combination of the importance given to the individual together with the space conceded to the community allows the cosmopolitan perspective to become a non-conflictual object of allegiance, as well as a privileged frame for the construction of a hegemonic discourse.

Also, strong in the cosmopolitan conception is the idea of distributive justice as the point of departure for a capacitation of the subject in order to become an "active citizen" and an "active individual" in a democratic space. An idea that is coincident with how democracy is understood according to what we have mentioned as the democratic revolution, that is, a place of multiple political spaces, composed by an essential difference that is articulated contingently. Within this capacitation through a distributive justice in the democratic space an important point in the cosmopolitan discourse is the insistence on the rights of the individual as possessor of a part of the common resources of humanity. As pointed before, this discourse is not one based in a modernized jusnaturalism, that is, defending what is owed to the individual prior to its incorporation on the social space, but is one that considers what is fundamental to the liberty of the subject as inserted in social relations. The capacitation of the individual through the acknowledgment of her right to be a possessor of a common property that is defined mainly as natural resources (paying attention thus to their nature as renewable and non-renewable, to the product of their use and how this relates to the right each individual has to the source of origin of the industrial activity, etc.) within the context of social interaction and the political construction of autonomous positions of equality, offers an opportunity to create a discourse of equivalence without establishing a totalitarian identity necessarily opposed to the "Other". There is no- "Other" to the cosmopolitan position. Liberty and equality are rescued in the cosmopolitan discourse as mere elements for articulation, not for opposition.

\section{EU Cosmopolitical}

For the EU to have a hegemonic discourse and strategy able to function as a source of strong soft power towards its member countries, it should adopt a cosmopolitan discourse highlighting all the components of the cosmopolitan perspective just mentioned above. In fact, if we look into anti-cosmopolitan or communitarian literature ${ }^{20}$,

20. See as paradigmatic examples: M. Walzer, "The distribution of Membership”, in P. G. Brown, H. Shue(eds.), in National Autonomy and Its Limits, Rowman \& Lettlefield, Totowa, 1981, pp. 1-35; D. Miller, "The Ethical Significance of Nationality”, 
we can find all the elements that define the current relation of Europe with its member states, that is, a relation that is determined by the definition of the state as a primary object of allegiance based on structural or fundamental reasons related to what is considered its exclusive moral, juridical, or pragmatic characteristics. If communitarianism has proved to be the incorrect strategy form where to construct the European identity, it might be the case that the better option is to look into the discourse direct opposite, cosmopolitanism.

As a starting point, and in order to avoid becoming the negativity of right-wing European populism, Europe has to construct its hegemony through a cosmopolitan discourse that regards social and economic justice. A discourse concerning the individual as an active subject, independently of its social affiliations and nationality, and with the capacity to interact in the social and political problematics that concern the different positions defining her liquid identity, and that conforms the social and political space of conflictuality. At the same time this discursivity considers the individual from the logic of the generality characteristic of cosmopolitanism, that is, from the logic of equality. To this equality cosmopolitanism can add the element of liberty and autonomy that constitutes it as a discourse apt to represent the "democratic hegemonic position". The cosmopolitan idea of the "commons", we will see, would serve as the focus for the widening of the political spaces while at the same time contributing to the creation of this plastic identity through the acknowledgment of a common tradition and common objectives.

On this logic, the EU cosmopolitan hegemonizing strategy should regard the construction of a European identity through the proposal of specific policies regarding justice with the EU zone. The current EU program on Justice is nowadays focalized in granting EU citizens access to justice, movement, right of access to employment and so, mainly, constructed on a perception of the subject as a consumer and as a commodity. "Justice for citizens and justice for growth: a true European area of justice will make citizens' lives better and allow businesses to make full use of the single market", the subtitle of the EU document on policies and programs in plan until 2020 regarding the area of EU justice, fundamental rights and equality ${ }^{21}$, offers us an accurate description of what is today conceived as the European individual. She is regarded not as a subject of capacitation but as a subject of market, and it reflects a conception of the individual that is

in Ethics, 98,4, 1988, pp. 647-62; R. E. Goodin, “What Is So Special about Our Fellow Countrymen?”, in Ethics, 98, 4, 1998, pp. 663-686; M. Blake, "Distributive Justice, State Coercion, and Autonomy", in Philosophy and Public Affairs, 30, 30, 2001, pp. 257-296; D. Miller, "National Responsibility and Global Justice”, in Critical Review of International Social and Political Philosophy, 11, 4, 2008, pp. 383-399.

21. See http://europa.eu/pol/rights/index_en.htm. 
far from cosmopolitan, but neoliberal oriented, centered on the individual as strongly commoditized.

While the commoditization of the subject is one of the factors defining the contemporary democratic "subject", it is precisely the confrontation to it and the confrontation arising from it that generates antagonisms and offers the possibility to create new political spaces. An insistence in rights aimed at reinforcing this commoditization cannot function as an articulatory element in the construction of hegemony but as a part of the "negative identity" that right-populism attaches to the $\mathrm{EU}$ as antagonistic force or oppressor. Instead, an insistence in the subject as one in struggle with her commodity dimension is what should be reflected in a European program of Justice. So, while the understanding of the contemporary subject of industrialized societies is not incorrect, its articulation in a justice program that mainly reflects the commoditization element without addressing the diverse demands for equity that spring from the opposition to it leaves the field of the propositionally in justice to the initiatives of the diverse European national parties. This creates in the long term a strong friction between the EU and its members, since any deviance from the strict $\mathrm{EU}$ economic growth expectations becomes a matter of conflict, being in origin a consequence of more extended justice programs than that offered by the EU.

The analysis of EU social justice shows an important decrease in all the areas of social justice and protection since the 2008 crisis $^{22}$. The EU discursive strategy and positive proposal for the social should concentrate in the capacitation of the individual from this perspective. It would imply an image of the individual as a primary object of concern not in its dimension of commoditization, but in its potentiality as a subject of political positioning, as a subject of different affiliations and demands. The capacitation of the individual as the main object of concern is thus one directed as her being a participant in the public political struggle, conscious that this public position is not in opposition to the private dimension, but blurred by it, strongly dependent on social justice politics and the way they affect the private life of the individual. Capacitating the individual not as a commodity, but as a subject of social justice is giving her the possibility to construct its plastic identity in a secure frame of action. A cosmopolitan Europe is not concerned with the states as subjects of stability, but with its individuals as the elemental units of its political, economic and social planning.

22. See https://www.tagesschau.de/wirtschaft/social-justice-index-101.pdf. 
Economic measures that concentrate on EU economic stability without concern for, or despite of, their effect on social justice and the life of the individuals, such as the ones established in the latter years following the global economic crisis, do nothing but mine the potential soft power that the EU has as an object of affiliation. They diminish its capacity to mediate in problematics related to strong political instabilities within its member states while at the same time facilitate the perspective and discourse that conceives EU as a source of oppression. The discourse on justice conceived from a cosmopolitan perspective might, if ever constructed, become one of the mayor sources of soft power within the EU.

Another part of the configuration of a hegemonic articulation should address what has become the nodal point for the opposed populist hegemonic discourses: the immigration problem and the status of the refugee within European legislation. This reformulation of the status of the refugee in Europe, according to a cosmopolitan perspective does not only address the idea of human rights and the individual considered as the ultimate unit of moral concern, but addresses the problematic of the immigration problem from a new perspective: that of collective responsibility. The extraterritorial application of human rights law by the European court of Justice shows the aim to widen the EU's concern regarding the rights of the individual, and the EU is one of the most important actors of international aid programs, as well as a leading force in the proposal and support of the Millennium Development Goals. Its role in humanitarian intervention is more disputable ${ }^{23}$, but all in all it might be declared that as a global actor the EU seems to already have the aura of a cosmopolitan actor. However, the problematic of massive immigration has brought to light the dark gap between its humanitarian image and the real approach determined by a multiplicity of opposed national interests. The problem labeled as "immigrant crisis" is an evidence of the current comprehension of the individual as a subject of the market. The fact that only asylum seekers are considered legal immigrants, while all the rest are considered illegal, establishes a delimitation of the subject and its potential legitimizing status as an object of legal concern based on its capacity, not to be a cosmopolitan subject, that is, to be an active individual, but in its potentiality for gain-productivity. The requisites for the request of asylum give evidence of a notion of universal citizenship very basic in its elements, and today superseded: that of the individual understood according its mere political identity. In this sense, a change of perspective, or an enlargement in

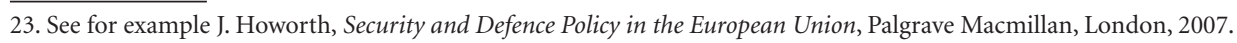


the consideration of the refugee status regarding the immigrant, with the inclusion of new categories to define an asylum seeker, such as the ones of ecological or economic refugee, might reinforce EU's cosmopolitical image both from within and from outside, while at the same time robing the populist discourse of what has been one of the principal subjects in their discourse elaboration.

This change of perspective regarding the immigrant opens the field also to the responsibility discourse, addressing the EU as a collective actor when accepting and redressing past and present harms. It contributes to the creation of the European identity offering the possibility of construction of a common European tradition, as well as conforming a point of convergence for the elaboration of common European objectives. Economic and ecological refugees might thus be viewed clearly as the consequence or result of past and present actions by advanced economies. To open the field of conflictuality towards the whole globe is not necessarily a strategy in soft power towards the outside, but allows, towards the inside, the creation of new nodes of convergence, the intensification of new political spaces where new identities are created. It enlarges the debate on justice and opens the field of discussion of social, economic and political policies to allow for the debate of an alternative reconfiguration of the global economy. If the immigrant is not viewed anymore as the main peril for our societies it might become the reason for more politics, more articulation, more decisions, for a European democracy. If the immigrant is not a tool for populisms it becomes then a weapon for cosmopolitanism. 